\title{
Characterization of a Selenium-Tolerant Rhizosphere Strain from a Novel Se-Hyperaccumulating Plant Cardamine hupingshanesis
}

\author{
Xinzhao Tong, ${ }^{1,2}$ Linxi Yuan, ${ }^{1,3,4}$ Lei Luo, ${ }^{3}$ and Xuebin Yin ${ }^{1,4}$ \\ ${ }^{1}$ Advanced Lab for Selenium and Human Health, Suzhou Institute for Advanced Study, University of Science and Technology of China, \\ Suzhou, Jiangsu 215123, China \\ ${ }^{2}$ Nano Science and Technology School, Suzhou Institute for Advanced Study, University of Science and Technology of China, \\ Suzhou, Jiangsu 215123, China \\ ${ }^{3}$ Jiangsu Bio-Engineering Centre on Selenium, Suzhou, Jiangsu 215123, China \\ ${ }^{4}$ School of Earth and Space Sciences, University of Science and Technology of China, Hefei, Anhui 230026, China
}

Correspondence should be addressed to Linxi Yuan; yuanli@ustc.edu.cn and Xuebin Yin; xbyin@ustc.edu.cn

Received 31 July 2014; Revised 4 October 2014; Accepted 5 October 2014; Published 12 November 2014

Academic Editor: Yudong Cai

Copyright ( $\odot 2014$ Xinzhao Tong et al. This is an open access article distributed under the Creative Commons Attribution License, which permits unrestricted use, distribution, and reproduction in any medium, provided the original work is properly cited.

A novel selenium- (Se-) hyperaccumulating plant, Cardamine hupingshanesis, accumulating Se as a form of SeCys ${ }_{2}$, was discovered in Enshi, Hubei, China, which could not be explained by present selenocysteine methyltransferase (SMT) theory. However, it is interesting to investigate if rhizosphere bacteria play some roles during $\mathrm{SeCys}_{2}$ accumulation. Here, one Se-tolerant rhizosphere strain, Microbacterium oxydans, was isolated from C. hupingshanesis. Phylogenetic analysis and 16S rRNA gene sequences determined the strain as a kind of Gram positive bacillus and belonged to the family Brevibacterium frigoritolerans. Furthermore, Se tolerance test indicated the strain could grow in extreme high Se level of $15.0 \mathrm{mg} \mathrm{Se} \mathrm{L}^{-1}$. When exposed to $1.5 \mathrm{mg} \mathrm{Se} \mathrm{L}^{-1}$, SeCys 2 was the predominant Se species in the bacteria, consistent with the Se species in C. hupingshanesis. This coincidence might reveal

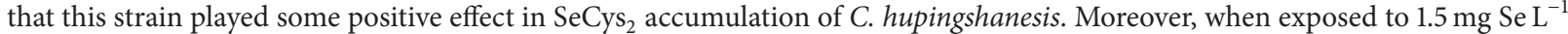
or $15.0 \mathrm{mg} \mathrm{Se} \mathrm{L}^{-1}$, As absorption diminished in the logarithmic phase. In contrast, As absorption increased when exposed to $7.5 \mathrm{mg}$ $\mathrm{Se} \mathrm{L}^{-1}$, indicating As metabolism processes could be affected by Se on this strain. The present study provided a sight on the role of rhizosphere bacteria during Se accumulation for Se-hyperaccumulating plant.

\section{Introduction}

Cardamine hupingshanesis from the selenium (Se), mine drainage area in Enshi, China was identified as a new Se secondary accumulating plant, and it could accumulate up to $99 \%$ of total Se in the form of $\mathrm{SeCys}_{2}$ without showing any phytotoxic symptoms [1]. This plant is quite different with the ever known Se-hyperaccumulating plants, Astragalus bisulcatus with methylselenocysteine (MeSeCys) $[2-5]$ and $\gamma$-glutamylmethylselenocysteine $[2,6]$, and Stanleya pinnata with MeSeCys [2, 7]. Presently, selenocysteine methyltransferase (SMT) was recognized as an important role on Se-hyperaccumulation because SMT could methylate SeCys to avoid its toxicity for related proteins $[8,9]$.
Moreover, the transgenic non-Se-hyperaccumulating plants, Arabidopsis thaliana and Brassica juncea (Indian mustard), overexpressing SMT could apparently accumulate Se in their tissues [10-12]. However, apparently, SMT theory could not give a reasonable explanation on $\mathrm{SeCys}_{2}$ hyperaccumulation in Cardamine hupingshanesis [1].

In recent years, some studies revealed that rhizosphere bacteria likely played an important role in facilitating the uptake of Se in Se hyperaccumulating plants [13, 14]. Astragalus bisulcatus apparently lived with a variety of Se-resistant ecological partners (e.g., microbial endosymbionts) to affect Se species in plants $[15,16]$. Rhizosphere bacteria increased Se enrichment and volatilization in Brassica juncea [16] and Indian Mustard [13] and similar phenomenon was also found 


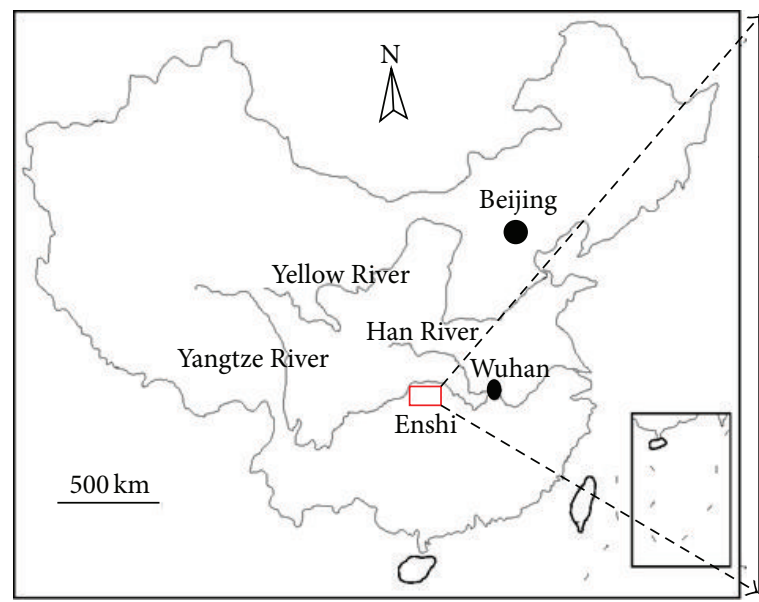

(a)

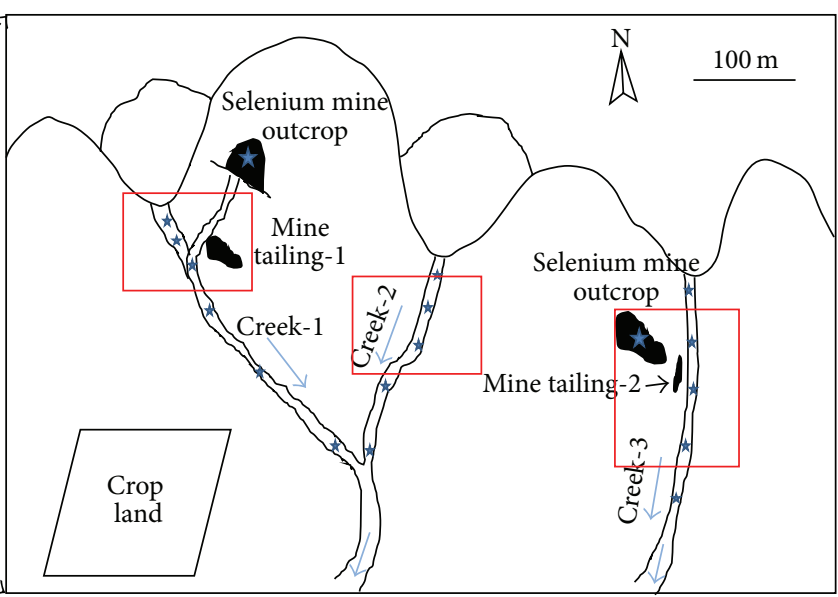

(b)

FIGURE 1: Study site and sampling: (a) the study area located in Enshi; (b) three sampling sites (red square) in selenium mine drainage areas.

in two wetland plants, saltmarsh bulrush and rabbit foot grass [13]. Moreover, S. alfredii, a kind of $\mathrm{Cd} / \mathrm{Zn}$ hyperaccumulating plant, can tolerate higher metal concentrations with the assistance of bacteria [17]. The Ni-resistant rhizosphere bacteria could serve as an effective metal-immobilizing and growth-promoting bioinoculant for $N$. caerulescens [18]. Thus, the present study focused on the rhizosphere bacteria from C. hupingshanesis, and the special subjects are as follows: (1) Se-resistant bacteria were isolated from the rhizosphere of C. hupingshanesis; (2) one of them was choose to investigate the selenite metabolic process.

Furthermore, since high contents of arsenic (As) were also found in the sampling site (unpublished data, $17.78 \pm$ $0.34 \mathrm{mg} \mathrm{As} \mathrm{kg}^{-1}$ ) and As could affect the Se accumulation via antagonism or synergism effects [19], the relationship between Se and As in the selected strain's metabolic processes was also studied.

\section{Materials and Methods}

2.1. Study Site Description. The study site is located in Enshi, western Hubei province of China, and it was so-called as "World Capital of Se" because of the only Se mine in the world there. Cardamine hupingshanesis, a new Se secondary accumulator, was collected from Se-mine drainage area, Yutangba, northern Enshi (Figure 1). In general, the Se contents in sediments from the study site varied from 10 to $70 \mathrm{mg} / \mathrm{kg}$ DW with exceptional high near Se mine tailings (274 \pm 152 $(n=3) \mathrm{mg} / \mathrm{kg} \mathrm{DW})$ [1]. High contents of As were also found in the rhizosphere soils of $C$. hupingshanesis (unpublished data, $\left.17.78 \pm 0.34(n=3) \mathrm{mg} \mathrm{As} \mathrm{kg}^{-1}\right)$.

2.2. Isolation of Rhizosphere Bacteria from C. hupingshanesis. Intact plants were dug out and their roots were chipped as 1 -cm-long segments to macerate in $50 \mathrm{~mL}$ tube with sterile distilled water. After vibrating for $1 \mathrm{~min}$, the homogenized suspensions were serially diluted to $10^{-6}$ times. Then, the diluted suspensions were plated on the surface of TSA medium with $200 \mu \mathrm{g} \mathrm{Se}\left(\right.$ as $\left.\mathrm{Na}_{2} \mathrm{SeO}_{3}\right) / \mathrm{L}$. Repeating the dilution and plating procedures till individual colony forming, the isolated rhizosphere strains were collected to store in glycerol stocks at $-80^{\circ} \mathrm{C}$.

2.3. Morphological, Physiological, and Biochemical Tests. One well-grown strain, labeled as Suzhou 08+6, was selected to do morphological, physiological, and biochemical tests. The light microscopy (Olympus BX51) was employed for morphological test. Physiological properties as well as enzyme activity tests and biochemical analysis (see Tables 2 and 3) were determined by the standard micromethod Api 20E. Those tests were performed in China Center for Type Culture Collection (CCTCC, Wuhan, China).

2.4. 16S rRNA Gene Sequencing. Genomic DNA was isolated from freshly grown culture (Suzhou 08+6) following the methods of Sambrook et al. (1989) [20]. The 16S rRNA gene was amplified using the universal primers $27 \mathrm{f}$ and $1492 \mathrm{r}$ [21], and the PCR products were sequenced by Invitrogen Biotechnology in CCTCC, Wuhan, China. The phylogenetic analysis was performed by using MEGA version 4.0 [22].

2.5. Total Se Analysis. The deposit (0.5-1g) or supernatant $(1 \mathrm{~mL})$ samples after centrifuge were digested by $\mathrm{HNO}_{3}$ and $\mathrm{HClO}_{4}(4: 1, \mathrm{v} / \mathrm{v})$ for $12 \mathrm{~h}$ and then $\mathrm{HCl}(12 \mathrm{M})$ for $3-4 \mathrm{~h}$ according to Gao et al. (2011) [23]. The total Se concentrations were determined by Hydride Generation Atomic Fluorescence Spectrometry (HG-AFS 9230) (Beijing Titan Instrument Co., China) with $0.75 \%$ RSD.

2.6. Total As Analysis. The deposit (0.5-1g) or supernatant $(1 \mathrm{~mL})$ samples after centrifuge were digested by $\mathrm{HNO}_{3}$ and $\mathrm{HClO}_{4}(4: 1, \mathrm{v} / \mathrm{v})$ for $12 \mathrm{~h}$ and then VC-thiourea $\left(50 \mathrm{~g} \mathrm{~L}^{-1}\right)$ for $2 \mathrm{~h}$ according to Bai et al. (2009) [24]. The total As concentrations were determined by Hydride Generation 


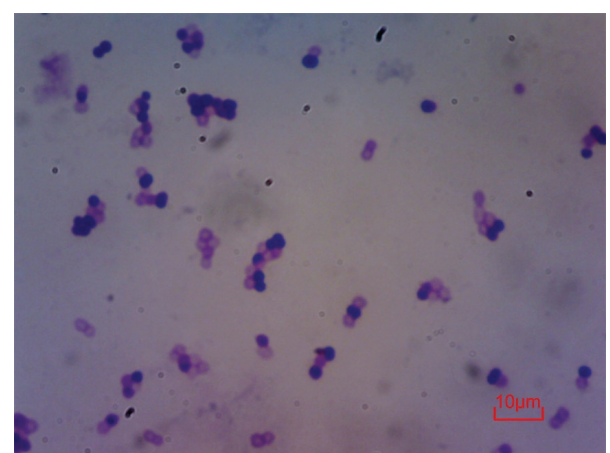

Figure 2: Cell morphology of isolated rhizospheric strain, Suzhou 08+6, under microscopy $\times 1000$ (Gram staining method).

Atomic Fluorescence Spectrometry (HG-AFS 9230) (Beijing Titan Instrument Co., China) with 1.37\% RSD.

2.7. Se Speciations Analysis. The deposition (0.2 g) or supernatant $(1 \mathrm{~mL})$ samples were attracted in Tris- $\mathrm{HCl}$ buffer $(100 \mathrm{mM}, \mathrm{pH} 7.5)$ and proteinase $(100 \mathrm{mM})$ for $14 \mathrm{~h}$ at $50^{\circ} \mathrm{C}$ and then protease XIV for $8 \mathrm{~h}$ at $37^{\circ} \mathrm{C}$ according to Liang et al. (2006) [25] and Mazej et al. (2006) [26]. The Se speciations were determined by liquid chromatography-UV irradiationhydride generation-atomic fluorescence spectrometry (LCUV-HG-AFS).

2.8. Growth Curve of Bacteria. Absorbance value of bacterial culture was determined at $\lambda=600 \mathrm{~nm}$ by Ultraviolet-Visible Pectrophotometer (UV-2450, Shimadzu) at different time intervals.

2.9. Design for Se and As Interaction Observations. Seven experimental groups and one control group were designed to observe the interactions between Se and As. The control group was added the isolated strain Suzhou 08+6 without Se or As. Three of the experimental groups were added with three different levels of Se (as selenite) $(1.5,7.5$, and $15.0 \mathrm{mg} \mathrm{L}^{-1}$ ) but no As. One of the experimental groups were only added with As (as sodium arsenate) as $0.5 \mathrm{mg} \mathrm{L}^{-1}$, and the other three experimental groups were added with three different levels of Se $\left(1.5,7.5\right.$, and $\left.15.0 \mathrm{mg} \mathrm{L}^{-1}\right)$ and one level of As $\left(0.5 \mathrm{mg} \mathrm{L}^{-1}\right)$ (Table 1$)$.

\section{Results and Discussion}

3.1. Identification of Rhizosphere Strain from Cardamine hupingshanesis. After successively culturing in $200 \mathrm{Se} \mu \mathrm{g} / \mathrm{L}$ mediums, 11 strains were collected, and one of them, named as Suzhou 08+6, was selected to be performed morphological, physiological, and biochemical traits. The observation under light microscopy displayed the isolated strain, Suzhou 08+6, could be a kind of Gram positive bacillus (Figure 2).

$16 \mathrm{~S}$ rRNA phylogenetic tree analysis revealed that Suzhou $08+6$ displayed a high similarity $(99.93 \%)$ to Brevibacterium frigoritolerans (GeneBank accession number DSM 8801(T)) (Figure 3). B. frigoritolerans, originally isolated from the arid soils of Morocco by Delaporte and Sasson (1967) [27], was a strictly aerobic chemoorganotrophic member of the genus Brevibacterium and had a unique feature on cold-resistance.

The physiological and biochemical analysis showed that Suzhou $08+6$ could grow in $2 \%$ or $5 \% \mathrm{NaCl}$ mediums and produce a series of active enzymes, including esterase (C4), esterase lipase (C8), naphthol-AS-BI-phosphate hydrolase, $\beta$-galactosidase, $\alpha$-glucosidase, and $\beta$-glucosidase (Table 2). In addition, the mannitol and amygdalin could be used as carbon sources by Suzhou 08+6 (Table 3).

Combined with above results, the isolated strain Suzhou $08+6$ was identified as Microbacterium oxydans.

3.2. Selenium Metabolic Characteristics of the Isolated Strain Suzhou 08+6. To investigate the tolerant Se-levels of Suzhou 08+6 (Microbacterium oxydans), the strain was grown in liquid TSB with $0,1.5,7.5$, and $15.0 \mathrm{mg} \mathrm{Se} \mathrm{L}^{-1}$, respectively, and the kinetics of bacteria growth was traced by OD 600 in the cultures. The results (Figure 4) showed that Suzhou $08+6$ could normally grow in those four different cultures, even in the extreme high level of $15.0 \mathrm{mg} \mathrm{Se} \mathrm{L}^{-1}$, indicating the strain could be a sort of Se-tolerant bacterium. The isolated strain was characterized by logarithmic phase in first $8 \mathrm{~h}$ and stationary phase in the following 8-120 h. Overall, there were no obvious differences among CK, Se 1.5, and Se 7.5. However, the absorbance values in $15.0 \mathrm{mg} \mathrm{Se} \mathrm{L}^{-1}$ group were $30 \%$ less than those in the other three groups, especially during stationary phase, suggesting that Se concentrations in the medium $\left(>7.5 \mathrm{mg} \mathrm{Se} \mathrm{L}^{-1}\right)$ are likely the limiting factor for Suzhou 08+6 growth. Tetteh et al. (2014) revealed that $5 \mathrm{mM} \mathrm{Na}_{2} \mathrm{SeO}_{3}$ treatment inhibited $E$. coli growth by $50 \%$, whereas 0.001 to $0.01 \mathrm{mM} \mathrm{Na}_{2} \mathrm{SeO}_{3}$ treatments stimulated cell growth by $30 \%$. In addition, cell numbers drastically decreased when treated with $50 \mathrm{mM}$ or higher $\mathrm{Na}_{2} \mathrm{SeO}_{3}[28$, 29]. This phenomenon could be attributed to the interactions between Se and enzymes [30, 31], and Se probably exerts inhibiting effect on the activity of enzymes with the catalysis oxidation reactions of S-H groups to $\mathrm{S}-\mathrm{S}$ or $\mathrm{S}-\mathrm{Se}-\mathrm{S}$ bonds [32].

Suzhou $08+6$ was cultured in liquid TSB with $1.5 \mathrm{mg} \mathrm{Se} \mathrm{L}^{-1}$ to observe its Se metabolic process.

HG-AFS and LC-UV-HG-AFS analysis indicated that Se (IV) in culture medium was actively consumed by bacteria in exponential phase, and SeMeCys $\left(1.77 \mathrm{mg} \mathrm{kg}^{-1}\right)$ was detected in deposit at $4 \mathrm{~h}$ (Table 4). After six hours, selenite contents diminished by $66 \%$ of the initial value in the supernatant, and Se achieved at a maximum concentration $\left(130 \mathrm{mg} \mathrm{Se} \mathrm{kg}^{-1}\right)$ in the deposits (Figure 5). The predominant Se species in the deposits was $\mathrm{SeCys}_{2}$, which was accounted for more than $80 \%$ of total Se during the culture period. Moreover, SeMeCys and Se (IV) were also detected in bacterial deposit. In contrast, the primary Se species in supernatant was Se (IV) and the content of total Se was decreased gradually in exponential phase (Table 4). However, as the strain growth entered into stationary phase, selenite contents in the supernatant increased by $30 \%$, which might be attributed to the Se absorption reduced $70 \%$ in bacteria (Figure 4). The contents of Se species such as $\mathrm{SeCys}_{2}$ in the deposits decreased steadily, from $14.09 \mathrm{mg} \mathrm{kg}^{-1}$ 
TABLE 1: Experimental design of the metabolic process of the isolated bacteria on Se and As.

\begin{tabular}{lcccc}
\hline & No Se & $\begin{array}{c}\text { Low-level Se } \\
\left(1.5 \mathrm{mg} \mathrm{L}^{-1}\right)\end{array}$ & $\begin{array}{c}\text { Middle-level Se } \\
\left(7.5 \mathrm{mg} \mathrm{L}^{-1}\right)\end{array}$ & $\begin{array}{c}\text { High-level Se } \\
\left(15 \mathrm{mg} \mathrm{L}^{-1}\right)\end{array}$ \\
\hline No As & CK & Se 1.5 & Se 7.5 & Se 15.0 \\
As $\left(0.5 \mathrm{mg} \mathrm{L}^{-1}\right)$ & As 0.5 & Se $1.5+$ As 0.5 & Se 7.5 + As 0.5 & Se $15.0+$ As 0.5 \\
\hline
\end{tabular}

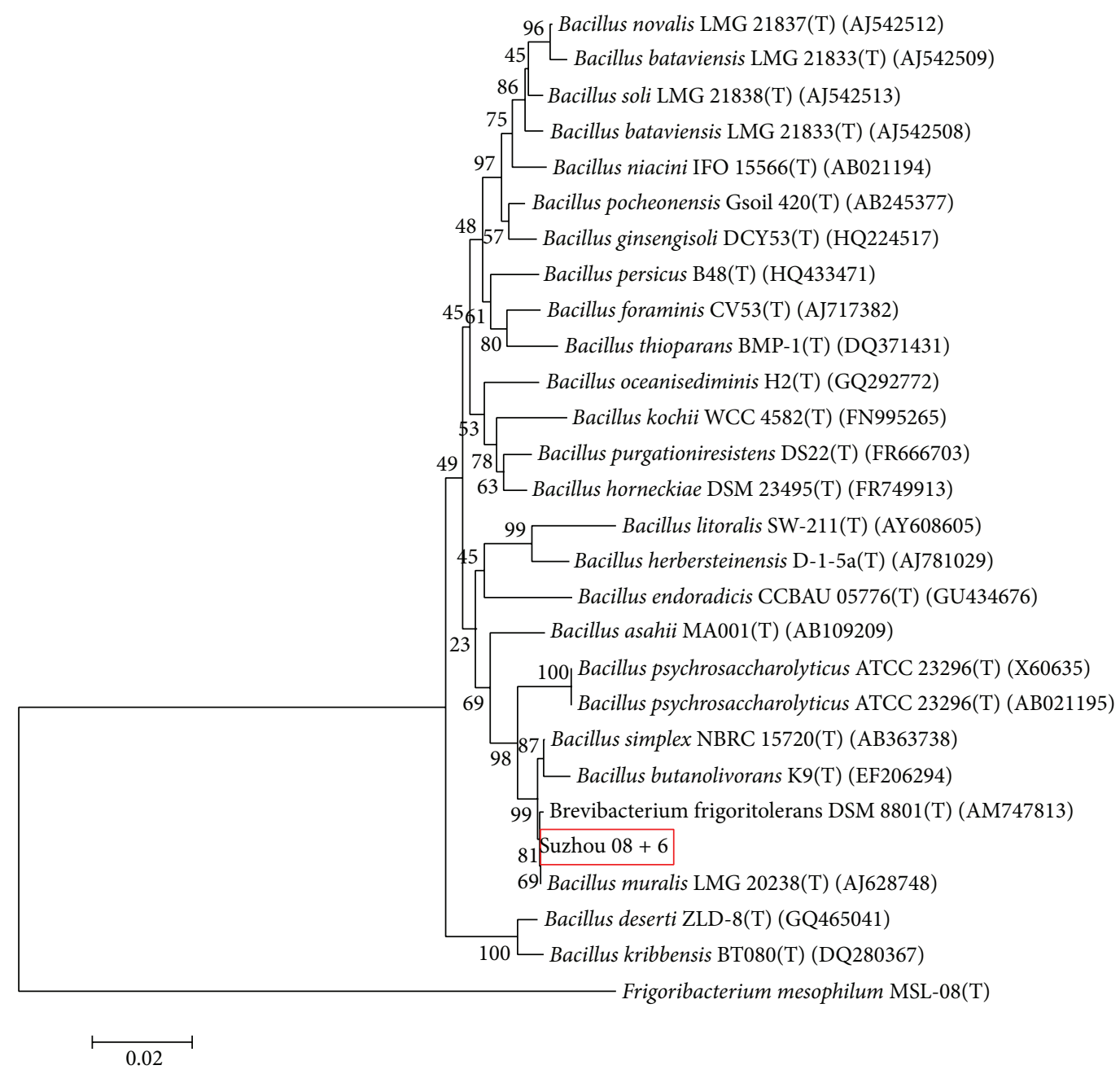

FIgURE 3: Phylogenetic positions based on neighbour-joining of the 16S rRNA gene sequence of the isolated rhizosphere strain, Suzhou $08+6$.

TABLE 2: The growth characteristics and enzyme activity of the isolated strain Suzhou $08+6$.

\begin{tabular}{lccc}
\hline Characteristics & Results & Characteristics & Results \\
\hline Growth on $2 \%, 5 \% \mathrm{NaCl}$ & + & Acid phosphatase (ACP) & - \\
Amylase & - & Naphthol-AS-BI-phosphate hydrolase & $\alpha$-Galactosidase \\
Alkaline phosphatase & - & $\beta$-Galactosidase \\
Esterase $(\mathrm{C} 4)$ & + & $\beta$-Glucuronidase & - \\
Esterase lipase $(\mathrm{C} 8)$ & + & $\alpha$-Glucosidase \\
Lipase $(\mathrm{C} 14)$ & - & $\beta$-Glucosidase & - \\
Leucine arylamidase & - & N-Acetyl glucosamine-enzyme \\
Valine arylamidase & - & $\alpha$-Mannosidase \\
Cystine arylamidase & - & $\beta$-Fucosidase \\
Trypsin & - & & - \\
Chymotrypsin & - & - \\
\hline
\end{tabular}

+: presence of a trait; -: absence of a trait. 
TABLE 3: API 20 enzymes and carbon source fermentation on the isolated strain Suzhou 08+6.

\begin{tabular}{lcccc}
\hline Characteristics & Results & Characteristics & Results \\
\hline$\beta$-Galactosidase & - & Gelatinase & - \\
Arginine hydrolase & + & Glucose fermentation/oxidation & - \\
Lysine decarboxylase & - & Mannitol Fermentation/oxidation & + \\
Ornithine decarboxylase & - & Inositol fermentation/oxidation & - \\
The use of citric acid & - & Sorbitol fermentation/oxidation & - \\
$\mathrm{H}_{2} \mathrm{~S}$ production & - & Rhamnose fermentation/oxidation & - \\
Urease & - & sucrose fermentation/oxidation & - \\
Tryptophan deaminase & + & Melibiose fermentation/oxidation & - \\
Indole production & - & Amygdalin fermentation/oxidation & + \\
Acetoin production & + & Arabinose fermentation/oxidation & - \\
\hline
\end{tabular}

+: presence of a trait; -: absence of a trait.

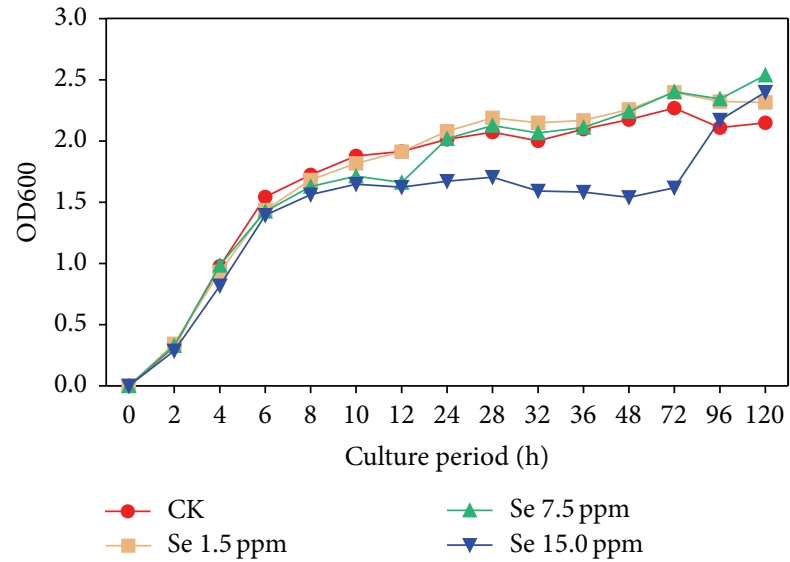

FIGURE 4: Growth curves of isolated strain in different Se medium. CK: growth in the culture without selenite; Se 1.5: grow in the culture with $1.5 \mathrm{mg} \mathrm{Se} \mathrm{L}^{-1}$; Se 7.5: grow in the culture with $7.5 \mathrm{mg} \mathrm{Se} \mathrm{L}^{-1}$; Se 15.0: grow in the culture with $15 \mathrm{mg} \mathrm{Se} \mathrm{L}^{-1}(n=5)$.

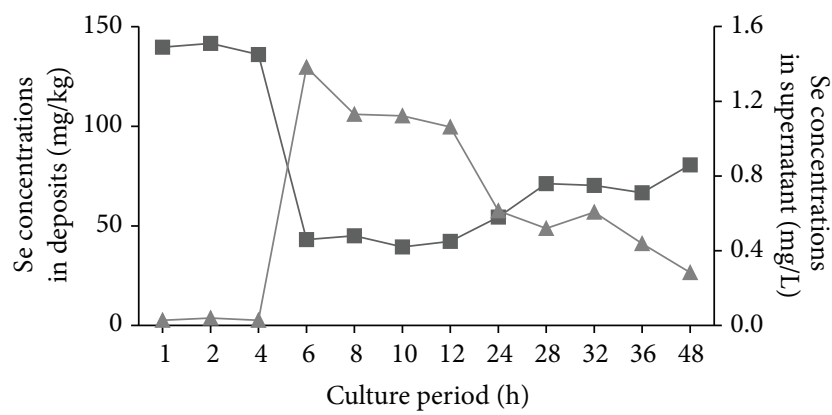

Figure 5: Se concentrations in the supernatant and deposit. $\mathbf{\square}$ : Se concentrations in supernatant $\left(\mathrm{mg} \mathrm{L}^{-1}\right) ; \boldsymbol{\Delta}$ : Se concentrations in deposit $\left(\mathrm{mg} \mathrm{kg}^{-1}\right)$.

at $6 \mathrm{~h}$ to $2.64 \mathrm{mg} \mathrm{kg}^{-1}$ at $48 \mathrm{~h}$. Thus, the isolated bacterium, Suzhou 08+6 (Microbacterium oxydans), could transform Se (IV) into $\mathrm{SeCys}_{2}$, which was consistent with the dominant Se speciation accumulated in C. hupingshanesis [1].

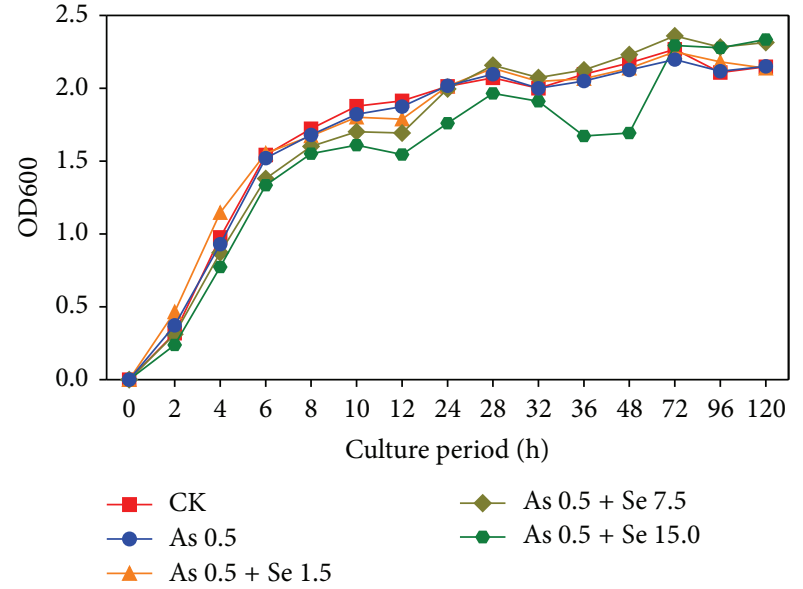

FIGURE 6: The growth of the isolated strain, Suzhou $08+6$, in the culture medium with different concentration of Se and As. One control group and four experimental groups with $0.5 \mathrm{mg} \mathrm{As} \mathrm{L}^{-1}$ and different concentration of Se $\left(0,1.5 \mathrm{mg} \mathrm{Se} \mathrm{L}^{-1}, 7.5 \mathrm{mg} \mathrm{Se} \mathrm{L}^{-1}\right.$, and $\left.15.0 \mathrm{mg} \mathrm{Se} \mathrm{L}^{-1}\right)$ in the culture medium $(n=5)$.

3.3. Interactions between Se and As in the Metabolic Process of the Isolated Strain. To study the interactions between Se and As, Suzhou 08+6 was grown in liquid TSB with different concentrations of selenite and arsenic (Table 1 ). The results displayed that Suzhou $08+6$ could grow in five different culture mediums (Figure 6). Overall, there were no obvious differences among CK, As $0.5+$ Se 1.5, and As $0.5+$ Se 7.5. However, high concentration of selenite $\left(15.0 \mathrm{mg} \mathrm{Se} \mathrm{L}^{-1}\right)$ might have a strong inhibited effect on strain growth during the culture period in As $0.5+$ Se 15.0 group.

HG-AFS analysis showed that total As in the supernatant was increased about $30 \%$ in the logarithmic phase with the presence of $1.5 \mathrm{mg} \mathrm{Se} \mathrm{L}^{-1}$ (Figure 7(a)) and $15.0 \mathrm{mg} \mathrm{Se} \mathrm{L}^{-1}$ (Figure 7(c)), indicating As absorption in the strain decreased under Se stress in these two groups. However, total As in supernatant diminished by $50 \%$ during logarithmic phase and stationary phase with the presence of $7.5 \mathrm{mg} \mathrm{Se} \mathrm{L}^{-1}$ (Figure 7(b)), indicating As absorption in the strain was increased under Se stress in this group. 
TABle 4: Concentrations of Se speciations $\left(\mathrm{Se}^{4+}, \mathrm{SeCys}_{2}\right.$, SeMecys, and SeMet) in the supernatant and deposit. (The isolated strain, Suzhou $08+6$, was grown in the culture medium with $1.5 \mathrm{mg} \mathrm{Se} \mathrm{L}^{-1}$ ).

\begin{tabular}{|c|c|c|c|c|c|c|c|c|}
\hline \multirow{2}{*}{ Time } & \multicolumn{4}{|c|}{ Se speciation concentrations in supernatant $\left(\mathrm{mg} \mathrm{L}^{-1}\right)$} & \multicolumn{4}{|c|}{ Se speciation concentrations in deposit $\left(\mathrm{mg} \mathrm{kg}^{-1}\right)$} \\
\hline & $\mathrm{Se}^{4+}$ & $\mathrm{SeCys}_{2}$ & SeMeCys & SeMet & $\mathrm{Se}^{4+}$ & $\mathrm{SeCys}_{2}$ & SeMeCys & SeMet \\
\hline $1 \mathrm{~h}$ & 1.54 & - & - & - & $*$ & $*$ & $*$ & $*$ \\
\hline $2 \mathrm{~h}$ & 1.57 & - & - & 0.02 & * & * & * & * \\
\hline $4 \mathrm{~h}$ & 1.52 & - & - & - & - & - & 1.77 & - \\
\hline $6 \mathrm{~h}$ & 0.03 & - & - & - & 0.37 & 14.09 & - & - \\
\hline $8 \mathrm{~h}$ & 0.08 & - & - & - & - & 22.20 & - & - \\
\hline $10 \mathrm{~h}$ & 0.06 & - & - & - & - & 12.26 & 3.54 & - \\
\hline $12 \mathrm{~h}$ & 0.07 & - & - & - & - & 22.05 & - & - \\
\hline $24 \mathrm{~h}$ & 0.07 & - & - & - & 0.19 & 7.06 & - & - \\
\hline $28 \mathrm{~h}$ & 0.11 & - & - & - & 0.10 & 12.19 & - & - \\
\hline $32 \mathrm{~h}$ & 0.08 & - & - & - & 0.20 & 11.92 & - & - \\
\hline $36 \mathrm{~h}$ & 0.07 & - & - & - & 0.23 & 7.42 & - & - \\
\hline $48 \mathrm{~h}$ & 0.07 & - & - & - & - & 2.64 & - & - \\
\hline
\end{tabular}

-: below the detection limit; $*$ : no sample.

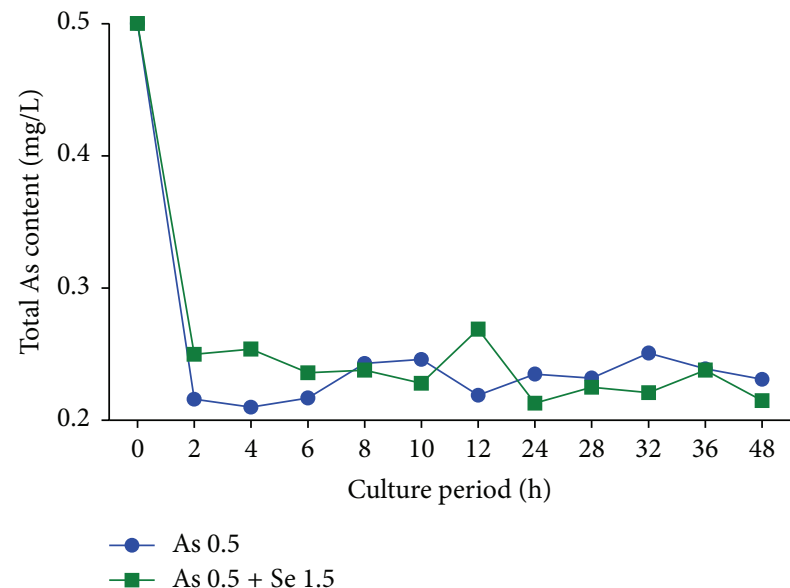

(a)

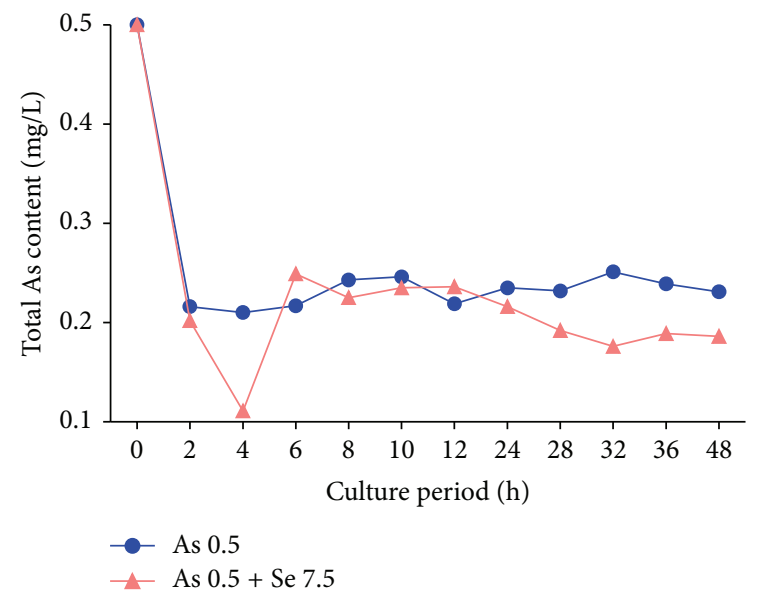

(b)

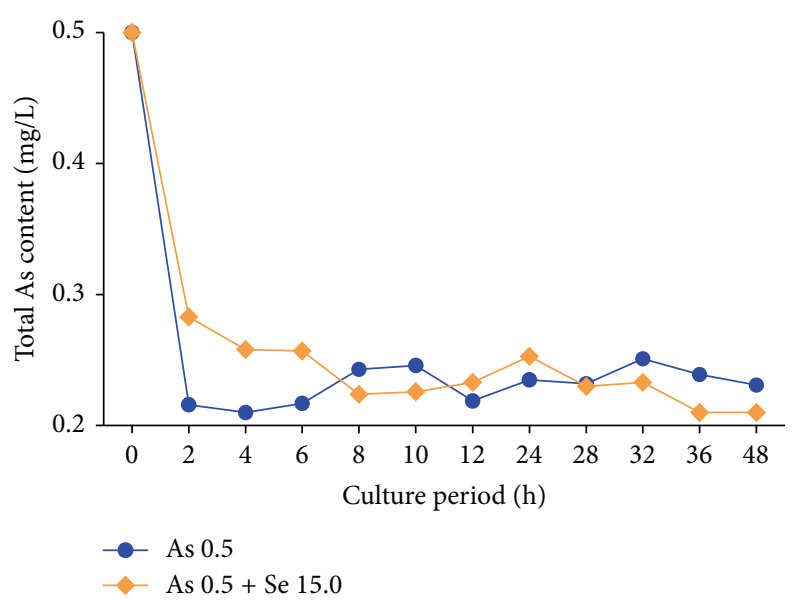

(c)

Figure 7: The content of total As in supernatant of different experimental groups. (a) As 0.5, As $0.5+$ Se 1.5 (b) As 0.5 , As $0.5+$ Se 7.5 (c) As 0.5, and As $0.5+$ Se 15.0. 
The above results indicated that the interactions between Se and As on Suzhou 08+6 depended on Se and As levels in culture mediums. Under arsenic stress ( $\left.0.5 \mathrm{mg} \mathrm{As} \mathrm{L}^{-1}\right)$, Se could inhibit As absorption at the level of below $1.5 \mathrm{mg} \mathrm{Se} \mathrm{L}^{-1}$ or above $15.0 \mathrm{mg} \mathrm{Se} \mathrm{L}^{-1}$. But the strain growth would be strongly inhibited at the level of $15.0 \mathrm{mg} \mathrm{Se}^{-1}$, compared with no inhibition at the level of $1.50 \mathrm{mg} \mathrm{Se} \mathrm{L}^{-1}$ Interestingly, Se could promote As absorption at the moderate levels (e.g., $7.5 \mathrm{mg} \mathrm{Se} \mathrm{L}^{-1}$ ), without showing obvious effect on strain growth.

Zhou et al. (1987) revealed that $5 \mathrm{mg} \mathrm{L}^{-1}$ or lower Se might antagonize As absorption, whereas $10 \mathrm{mg} \mathrm{L}^{-1}$ Se could synergize As absorption on Photobacterium Phosphoreum T3 [33]. When E. coli was exposed to $89 \mathrm{~g} \mathrm{~L}^{-1}$ or $178 \mathrm{~g} \mathrm{~L}^{-1}$ selenomorpholine, Se significantly antagonized As absorption. However, when exposed to a higher selenomorpholine (446 $\mathrm{g} \mathrm{L}^{-1}$ ), Se only has antagonistic effects on As absorption with higher As $\left(6-8 \mathrm{~g} \mathrm{~L}^{-1}\right)$ and has cooperative interaction with lower As (1-4 $\left.\mathrm{g} \mathrm{L}^{-1}\right)$ [19].

\section{Conclusions}

One Se-tolerant rhizosphere strain, Microbacterium oxydans, was isolated from Cardamine hupingshanesis and identified as a family of Brevibacterium frigoritolerans by $16 \mathrm{~S}$ rRNA phylogenetic analysis. Se tolerance test indicated that the isolated strain could grow in extreme high Se level of $15.0 \mathrm{mg} \mathrm{Se} \mathrm{L}^{-1}$. When exposed to $1.5 \mathrm{mg} \mathrm{Se} \mathrm{L}^{-1}, \mathrm{SeCys}_{2}$ was the predominant Se species in the bacterial deposits, which is coincided with the dominant Se species in C. hupingshanesis, indicating this kind of Se-tolerant strain played some positive effects in $\mathrm{SeCys}_{2}$ accumulation of C. hupingshanesis. Moreover, $\mathrm{Se}$ and As interactions on this isolated strain were also studied. When exposed to $1.5 \mathrm{mg} \mathrm{Se} \mathrm{L}^{-1}$ or $15.0 \mathrm{mg} \mathrm{Se} \mathrm{L}^{-1}$, As absorption diminished by $20-30 \%$ in the logarithmic phase. In contrast, As absorption increased when exposed to $7.5 \mathrm{mg} \mathrm{Se} \mathrm{L}^{-1}$.

\section{Conflict of Interests}

The authors declare that there is no conflict of interests regarding the publication of this paper.

\section{Acknowledgments}

This work was funded by National Natural Science Foundation of China (NNSFC31400091), Natural Science Foundation of Jiangsu Province (BK2012202), Chinese Postdoctoral Science Foundation (2013M540518), and Jiangsu Provincial Postdoctoral Science Foundation (1302080C).

\section{References}

[1] L. Yuan, Y. Zhu, Z.-Q. Lin, G. Banuelos, W. Li, and X. Yin, "A novel selenocystine-accumulating plant in selenium-mine drainage Area in Enshi, China," PLoS ONE, vol. 8, no. 6, Article ID e65615, 2013.
[2] J. L. Freeman, L. H. Zhang, M. A. Marcus, S. Fakra, S. P. McGrath, and E. A. H. Pilon-Smits, "Spatial imaging, speciation, and quantification of selenium in the hyperaccumulator plants Astragalus bisulcatus and Stanleya pinnata," Plant Physiology, vol. 142, no. 1, pp. 124-134, 2006.

[3] T. K. Virupaksha and A. Shrift, "Biochemical differences between selenium accumulator and non-accumulator astragalus species," Biochimica et Biophysica Acta-General Subjects, vol. 107, no. 1, pp. 69-80, 1965.

[4] P. M. Dunnill and L. Fowden, "The amino acids of the genus Astragalus," Phytochemistry, vol. 6, no. 12, pp. 1659-1663, 1967.

[5] J. L. Freeman, M. Tamaoki, C. Stushnoff et al., "Molecular mechanisms of selenium tolerance and hyperaccumulation in Stanleya pinnata," Plant Physiology, vol. 153, no. 4, pp. 16301652, 2010.

[6] S. N. Nigam and W. B. McConnell, "Seleno amino compounds from Astragalus bisulcatus isolation and identification of $\gamma$-Lglutamyl-Se-methyl-seleno-L-cysteine and Se-methylseleno-Lcysteine," Biochimica et Biophysica Acta: General Subjects, vol. 192, no. 2, pp. 185-190, 1969.

[7] A. Shrift and T. K. Virupaksha, "Seleno-amino acids in selenium-accumulating plants," Biochimica et Biophysica Acta, vol. 100, no. 1, pp. 65-75, 1965.

[8] T. A. Brown and A. Shrift, "Selenium toxicity and tolerance in higher plants," Biologicla Reviews, vol. 57, no. 1, pp. 59-84, 1982.

[9] B. Neuhierl and A. Böck, "On the mechanism of selenium tolerance in selenium-accumulating plants," European Journal of Biochemistry, vol. 239, no. 1, pp. 235-238, 1996.

[10] D. R. Ellis, T. G. Sors, D. G. Brunk et al., "Production of Semethylselenocysteine in transgenic plants expressing selenocysteine methyltransferase," BMC Plant Biology, vol. 4, article $1,2004$.

[11] D. L. LeDuc, A. S. Tarun, M. Montes-Bayon et al., "Overexpression of selenocysteine methyltransferase in Arabidopsis and Indian mustard increases selenium tolerance and accumulation," Plant Physiology, vol. 135, no. 1, pp. 377-383, 2004.

[12] G. S. Bañuelos, D. L. LeDuc, E. A. H. Pilon-Smits, and N. Terry, "Transgenic Indian mustard overexpressing selenocysteine lyase or selenocysteine methyltransferase exhibit enhanced potential for selenium phytoremediation under field conditions," Environmental Science \& Technology, vol. 41, no. 2, pp. 599-605, 2007.

[13] M. P. de Souza, D. Chu, M. Zhao et al., "Rhizosphere bacteria enhance selenium accumulation and volatilization by Indian mustard," Plant Physiology, vol. 119, no. 2, pp. 565-573, 1999.

[14] T. G. Chasteen and R. Bentley, "Biomethylation of selenium and tellurium: microorganisms and plants," Chemical Reviews, vol. 103, no. 1, pp. 1-25, 2003.

[15] J. R. Valdez Barillas, C. F. Quinn, J. L. Freeman et al., "Selenium distribution and speciation in the hyperaccumulator Astragalus bisulcatus and associated ecological partners," Plant Physiology, vol. 159, no. 4, pp. 1834-1844, 2012.

[16] M. Montes-Bayón, E. G. Yanes, C. P. de León et al., "Initial studies of selenium speciation in Brassica juncea by LC with ICPMS and ES-MS detection: an approach for phytoremediation studies," Analytical Chemistry, vol. 74, no. 1, pp. 107-113, 2002.

[17] W. C. Li and M. H. Wong, "Interaction of Cd/Zn hyperaccumulating plant (Sedum alfredii) and rhizosphere bacteria on metal uptake and removal of phenanthrene," Journal of Hazardous Materials, vol. 209-210, pp. 421-433, 2012. 
[18] W. Aboudrar, C. Schwartz, J. L. Morel, and A. Boularbah, "Effect of nickel-resistant rhizosphere bacteria on the uptake of nickel by the hyperaccumulator Noccaea caerulescens under controlled conditions," Journal of Soils and Sediments, vol. 13, no. 3, pp. 501507, 2013.

[19] X. Li, Y. Liu, J. Wu, and S.-S. Qu, "Microcalorimetric study of the associated action of selenium to arsenic on the growth of Escherichia coli," Gaodeng Xuexiao Huaxue Xuebao/Chemical Journal of Chinese Universities, vol. 24, no. 1, pp. 91-94, 2003.

[20] J. Sambrook, E. F. Fritsch, and T. Maniatis, Molecular Cloning: A Laboratory Manual, Cold Spring Harbor Laboratory, Cold Spring Harbor, NY, USA, 1989.

[21] M. Dorsch, D. Lane, and E. Stackebrandt, "Towards a phylogeny of the genus Vibrio based on 16S rRNA sequences," International Journal of Systematic Bacteriology, vol. 42, no. 1, pp. 58-63, 1992.

[22] K. Tamura, J. Dudley, M. Nei, and S. Kumar, "MEGA4: Molecular Evolutionary Genetics Analysis (MEGA) software version 4.0," Molecular Biology and Evolution, vol. 24, no. 8, pp. 15961599, 2007.

[23] J. Gao, Y. Liu, Y. Huang et al., "Daily selenium intake in a moderate selenium deficiency area of Suzhou, China," Food Chemistry, vol. 126, no. 3, pp. 1088-1093, 2011.

[24] Y. Bai, Z. M. Ye, Z. Q. Lin, and J. K. Zhu, "Determination of total arsenic and inorganic arsenic in marine algae," Food Science, vol. 30, pp. 344-346, 2009.

[25] L. Liang, S. Mo, P. Zhang et al., "Selenium speciation by high-performance anion-exchange chromatography-postcolumn UV irradiation coupled with atomic fluorescence spectrometry," Journal of Chromatography A, vol. 1118, no. 1, pp. 139143, 2006.

[26] D. Mazej, I. Falnoga, M. Veber, and V. Stibilj, "Determination of selenium species in plant leaves by HPLC-UV-HG-AFS," Talanta, vol. 68, no. 3, pp. 558-568, 2006.

[27] B. Delaporte and A. Sasson, "Study of bacteria from arid soils of Morocco: Brevibacterium haloterans n. sp. and Brevibacterium frigoritolerans n. sp," Comptes Rendus Hebdomadaires des Séances de L'Académie des Sciences Série D: Sciences Naturelles, vol. 264, no. 18, pp. 2257-2260, 1967.

[28] A. Y. Tetteh, K. H. Sun, C.-Y. Hung et al., "Transcriptional response of selenopolypeptide genes and selenocysteine biosynthesis machinery genes in Escherichia coli during selenite reduction," International Journal of Microbiology, vol. 2014, Article ID 394835, 11 pages, 2014.

[29] M. Bébien, G. Lagniel, J. Garin, D. Touati, A. Verméglio, and J. Labarre, "Involvement of superoxide dismutases in the response of Escherichia coli to selenium oxides," Journal of Bacteriology, vol. 184, no. 6, pp. 1556-1564, 2002.

[30] C. A. Bayse and B. D. Allison, "Activation energies of selenoxide elimination from Se-substituted selenocysteine," Journal of Molecular Modeling, vol. 13, no. 1, pp. 47-53, 2007.

[31] Q. Liu, H. Wang, D.-C. Hu et al., "Effects of sodium selenite on telomerase activity and telomere length," Acta Biochimica et Biophysica Sinica, vol. 35, no. 12, pp. 1117-1122, 2003.

[32] L. Ding, X. Li, P. Liu, S. Li, and J. Lv, "Study of the action of $\mathrm{Se}$ and $\mathrm{Cu}$ on the growth metabolism of Escherichia coli by microcalorimetry," Biological Trace Element Research, vol. 137, no. 3, pp. 364-372, 2010.

[33] Z. Y. Zhou, C. Su, and J. Sun, "The influence of selenium and arsenic on Photobaeterium Phosphoreum T3-Se-As interaction in organism," Progress in Biochemistry and Biophysics, vol. 6, pp. 35-37, 1987. 

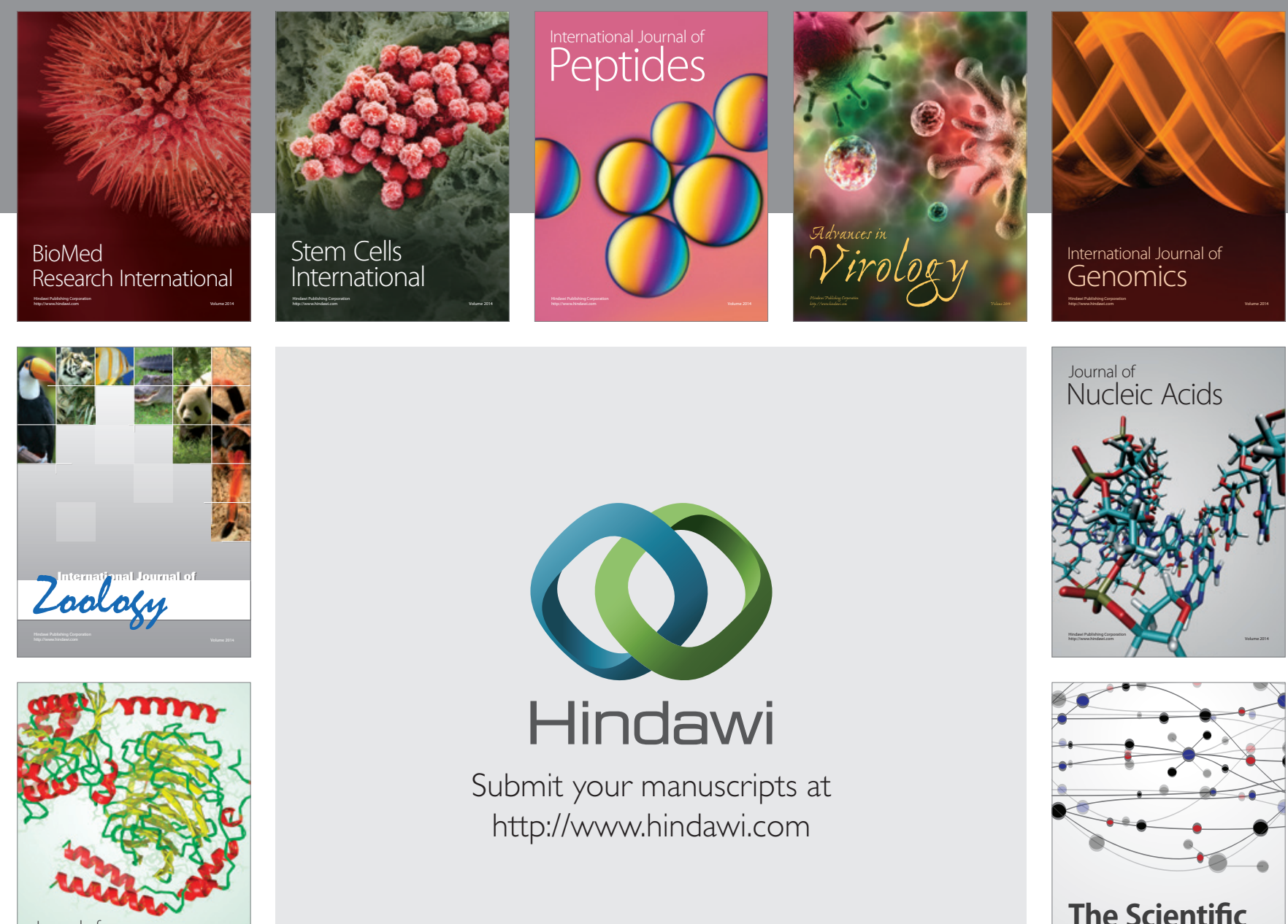

Submit your manuscripts at

http://www.hindawi.com

Journal of
Signal Transduction
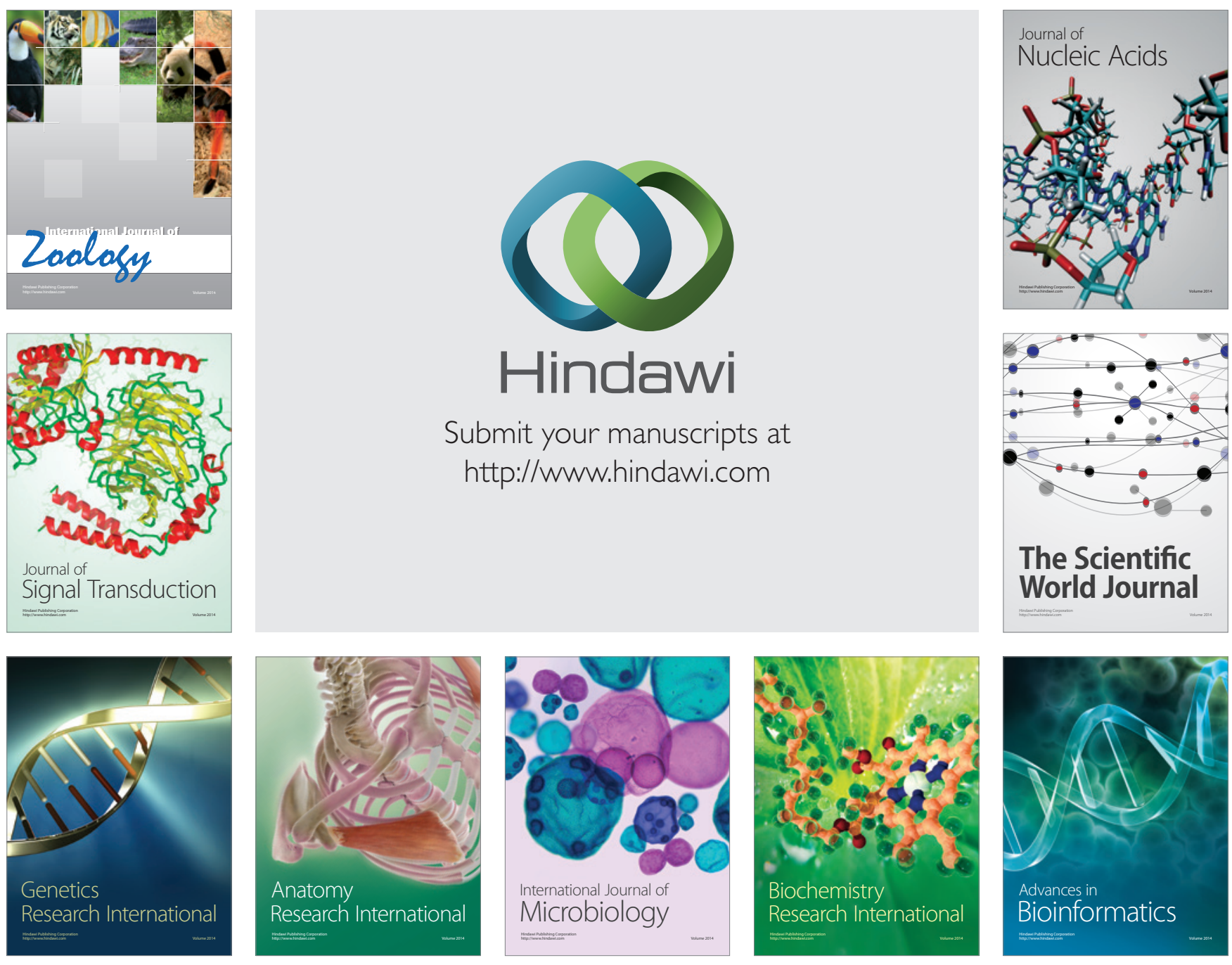

The Scientific World Journal
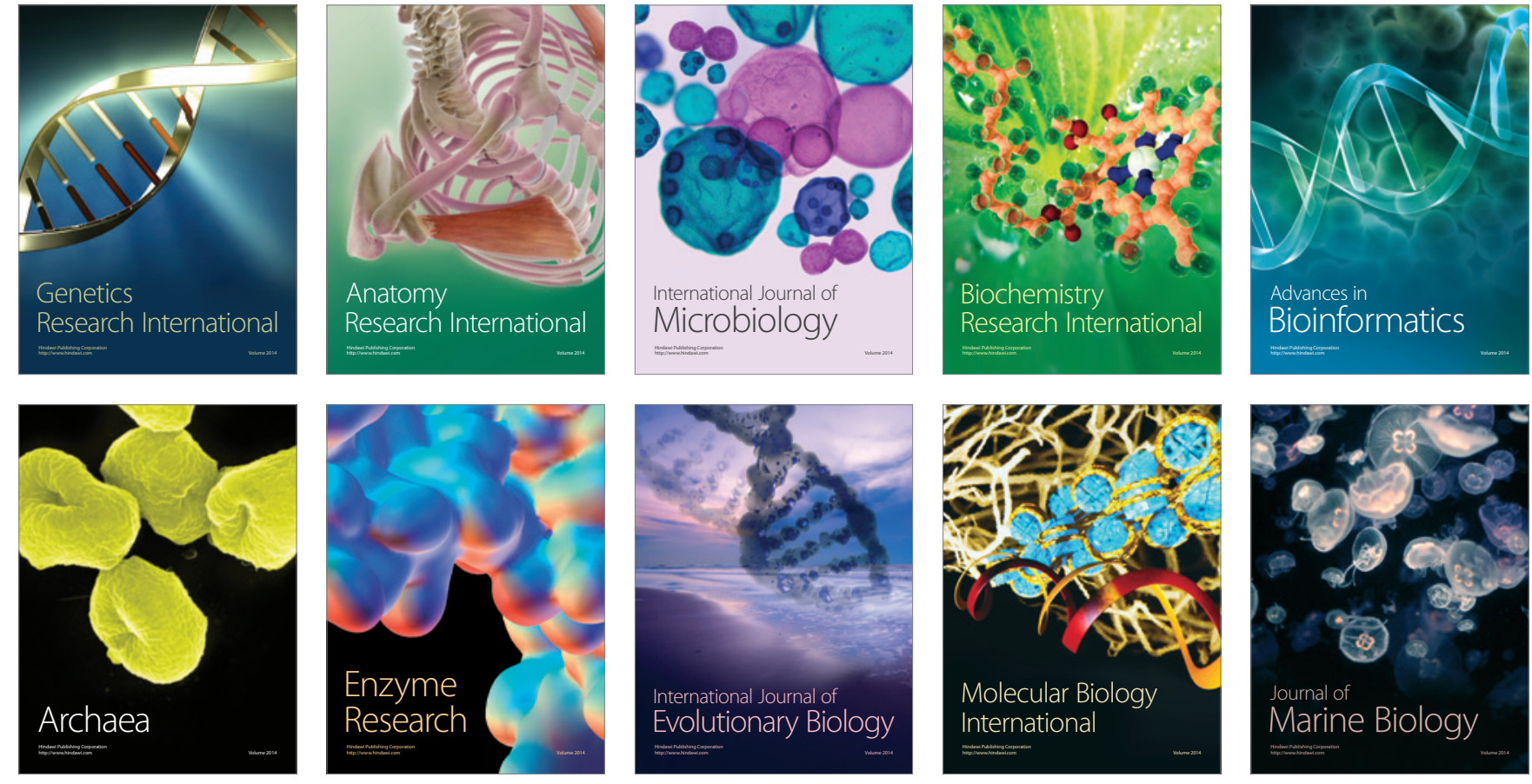